\title{
Landuse/Cover Change Trend in Soroti District Eastern Uganda
}

\author{
EGERU, A; MAJALIWA, M.GJ. \\ Institute Of Environment And Natural Resources, Makerere University \\ P.O. Box 7062. Kampala, Uganda. egeru81@educ.mak.ac.ug
}

\begin{abstract}
This study assessed the extent and trend of landuse/cover change in Soroti District, Uganda. A series of systematically corrected Orthorectified Landsat imageries of 1973, 1986 and 2001 were downloaded from the Landsat website. The images were analysed using unsupervised classification approach and the land-use/cover were validated and/or reconstructed by ground truthing, use of secondary data, and key informants. The study establishes that; small-scale farming was the major landuse type (24.2\%) and grasslands were the dominant landcover unit (26.1\%) in 1973. Small-scale farming however declined by $5.3 \%$ in 1986 due to prevailing insurgence at the time while grasslands gained by $2.9 \%$. In 2001, small-scale farming had increased by $13.6 \%$ at the expense of woodlands $(-2.3 \%)$, Bushlands $(-5.5 \%)$, Forest stock $(-2.2 \%)$ and wetlands $(-0.44)$ that experienced declines. This drastic gain in small-scale farming is likely to treat negative environmental effects such as intensity of floods and droughts, soil nutrient and biodiversity loss due habitat conversion. @JASEM
\end{abstract}

Landuse/cover changes have emerged as a global phenomenon and perhaps the most significant regional anthropogenic disturbance to the environment, especially in the $20^{\text {th }}$ Century because, dramatic landuse/cover changes that would have once required centuries now take place within a few decades and Africa is said to have the fastest rate of deforestation in the world as a result of overdependence on primary resources (Ademiluyi et al, 2008). In essence both landuse/cover changes are products of prevailing interacting natural and anthropogenic processes by human activities therefore, landuse/cover change detection allows for the identification of major processes of change (Fasona and Omojola, 2005).

The driving force for most landuse/cover changes is population growth (Ramankutty et al, 2002b) although there are several other interacting factors involved. There is a need to understand landuse/cover changes and its effect on the overall ecosystems (Lambin et al, 2003) as well as understanding local patterns and processes is important since landuse/cover change is closely linked to the sustainability of socio-economic development (Lambin et al. 1999). It is increasingly evident that a concatenation of variables interacts across spatial and temporal scales to cause landuse/cover changes and these casual clusters vary across regions and time (Mather et al. 1999) and areas affected by degradation can be identified and mapped from Landsat Thematic Mapper (TM) images (Raina et al, 1993). Consequently, in order to cope with the variability, it is vital to understand the past and present scenarios of landuse/cover so as to device appropriate adaptive mechanisms for enhanced sustainability. Therefore, this study seeks to assess the extent and trend of landuse/cover change in Soroti District.

\section{METHODOLOGY}

The study was conducted in Soroti District located between $1^{\circ} 28 \mathrm{~N}, 33^{\circ} 00 \mathrm{E}$ and $2^{\circ} 02 \mathrm{~N}, 33^{\circ} 31 \mathrm{E}$. The district is entirely located in a semi-arid area dominated by savannah grasslands characterized with thorny Accacia species. The North moist farmlands and North central farm bushlands with sandy soils are the main farming units. Series of systematically corrected Orthorectified Landsat imageries of 1973, 1986 and 2001 were downloaded from the Landsat website. The images were analysed using unsupervised classification approach and the landuse/cover were validated and/or reconstructed by ground truthing, use of secondary data, and key informants.

\section{RESULTS AND DISCUSSION}

In 1973, small scale farming was the dominant landuse $(24.17 \%)$ while grasslands $(26.07 \%)$ were the dominant landcover unit, and this was followed by woodlands cover at $12.43 \%$ hectares. Ironically there was still some forest standing stock (3.89\%) during this period (Fig 1and 2), this was mainly observed around the Lake Kyoga area and the islands in the lake. These areas receive higher precipitation than the rest of the district due to the influence of the Kyoga basin. After a thirteen year period, small scale farming had declined in hectares by $5.26 \%$ to $18.91 \%$ (1986) land utilization. This drop could be attributed to the prevailing insecurity at the time that had deprived the population of the opportunity to open land for cultivation. However, other landcover units gained in the same period including; wetlands $(2.18 \%)$, bush lands $(3.01 \%)$ and built up areas $(2.76 \%)$ These gains could be attributed to the fact that the land was left under fallow largely a function of insecurity (Fig 1). 


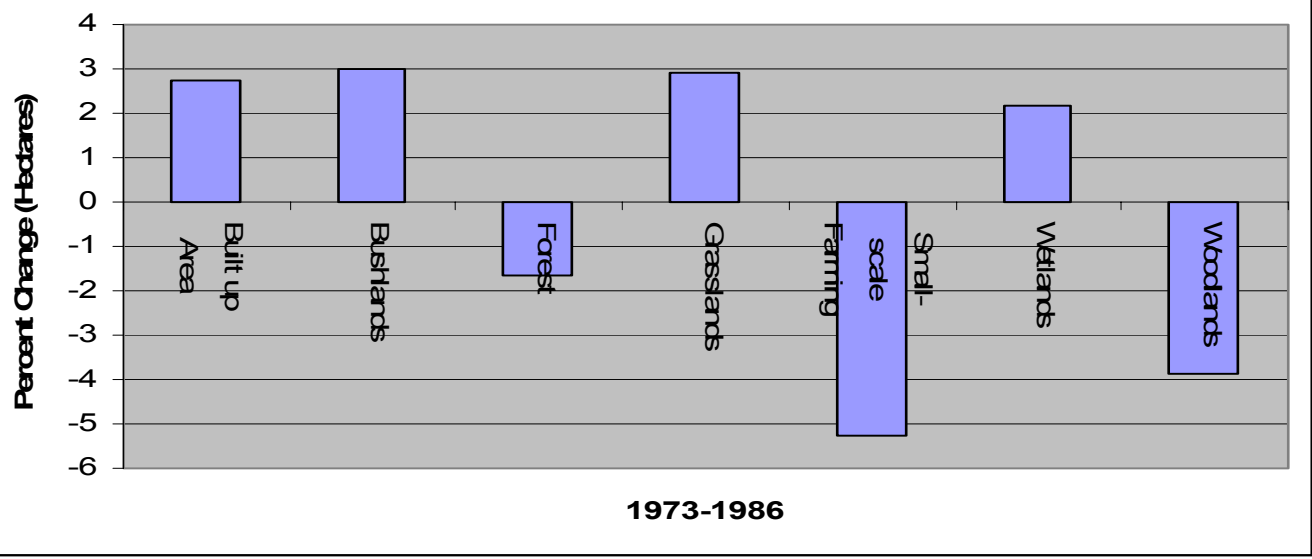

Fig 1: Landuse/cover Change Trend (1973-1986) Period.

In 2001 small-scale farming gained by $13.63 \%$ as the largest landuse in the area. This is due to the recovery efforts after the conflict in the sub-region, as there is prevailing peace households have engaged in cultivation for self reliance. This finding is in line with Esikuri (1998) findings in Amboseli- Kenya in which the major factor determining land use change is the growth in agriculture. The dominance of small scale farming in changing vegetation cover implies that on average $32.54 \%$ of hectares of the land area in the district is under cultivation in a single season. This has deprived vegetation cover regeneration potential consequently it has caused fuel wood scarcity, exposed large hectares to direct insolation, strong storms are being experienced, soil erosion and decline in crop yields as fallow periods have been shortened and increased frequency of livestock pests and diseases especially ticks and tsetse flies in the areas of Kyere, Kateta, Amusala and Pingere. The drastic gains in small scale farming is also partly responsible for various significant losses between 1986-2001 in other landcover units by given percent margins for example, woodlands $(-2.28 \%)$, bushland $(-5.54 \%)$ (Fig 2). These losses are due to more hectares being converted to cropland. This finding agrees with the analysis and aerial photo interpretation by Madebwe and Madebwe (2005) who concluded that vegetation loss was caused by increase in cultivated area and livestock numbers and this leads to a change in habitat structure where vegetation are removed reduces range and abundance of food resources and the extreme climatic conditions at the soil surface combine to create an environment beyond tolerance limits of most fauna groups which ignites trans-boundary migrations leading to spread of pests and faunal diseases.

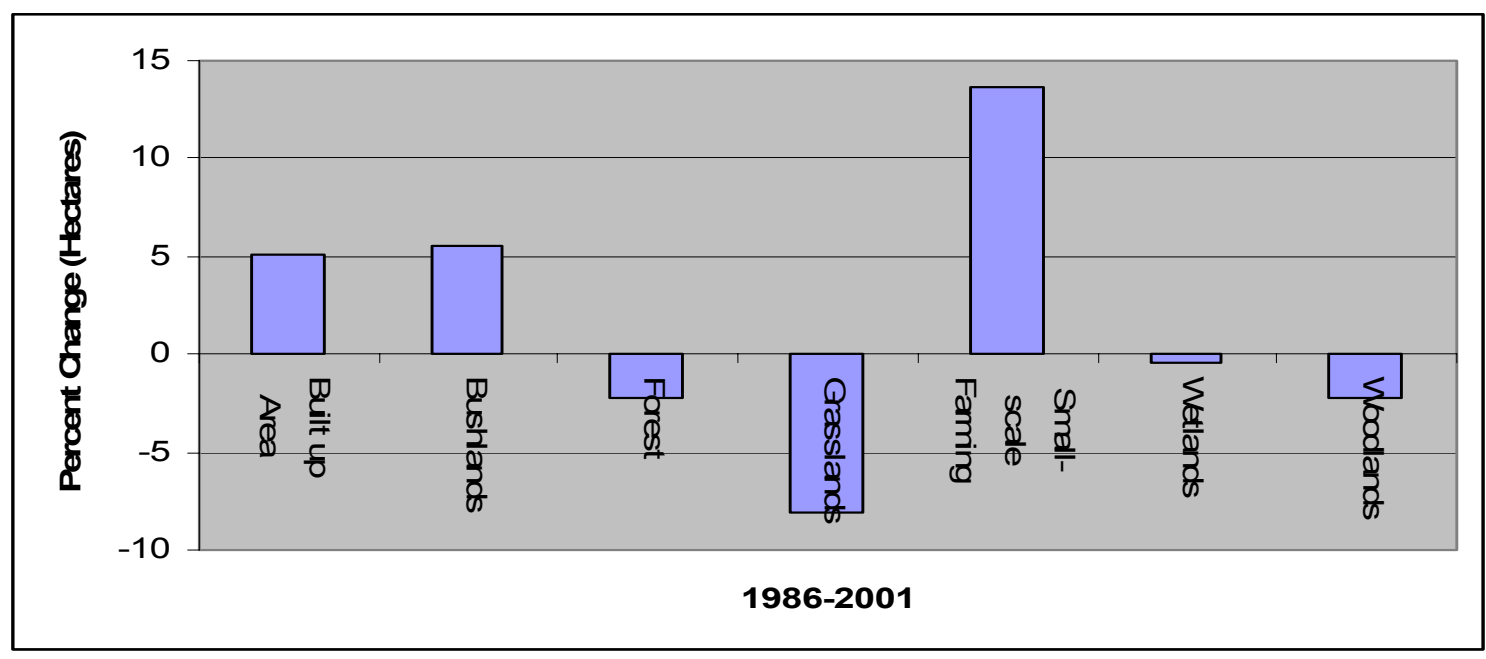

Fig 2: Landuse/cover Change Trend (1986-2001) Period. 
Conclusion: Landuse/cover change is driven by small-scale farming and is likely to lead to the expansion of xerophytic species which lead to decline in forage quality, increase competition for land with livestock, accelerate land degradation and induce negative climate change effects (Increased frequency and severity of floods and drought). These constitute challenges to the achievement of MDG1 and MDG 7 and one thing is certain, the communities in the district are bound to languish in this situation unless appropriate adaptive mechanisms for enhanced sustainability are taken.

Acknowledgement: We extend our gratitude to Regional University Forum (RUFORUM) for financial support rendered during the course of this study.

\section{REFERENCES}

Ademiluyi, I.A., Okude, A.S. and Akanni, C.O. (2008). An Appraisal of Landuse and Landcover Mapping in Nigeria. African Journal of Agricultural Research. Vol 3 (9) 581-586.

Esikuri, E.E.(1998). Spatio-Temporal Effects of Land Use Changes in Savanna Wildlife Area of Kenya. PhD Thesis, State University.
Fasona, M.J. and Omojola, A.S.(2005). Climate Change, Human Security and Communal Clashes in Nigeria. Paper Presented at an International Workshop on Human Security and Climate Change, Asker, Norway, 21-23 June, 2007.

Lambin, E.F., Geist, H.J and Lepers, E. (2003). Dynamics of land-use and

land-cover change in tropical regions, Environment \& Resources 28: 205-241.

Madebwe,V. and Madebwe, C (2005). An Exploratory Analysis of the Social, Economic and Environmental Impacts on Wetlands: The Case of Shurugwi District, Midlands Province, Zimbabwe. Journal of Applied Sciences Research 1(2), 228-233.

Mather, A. C. et al.(1999). Environmental Kuznets Curves and Forest Trends. Geography 84 (362), 5565.

Raina, P., Joshi, D.C and Kolarkar, A.S.(1993). Mapping of Soil Degradation by Using Remote Sensing on Alluvial Plain, Rajasthan, India. Arid Soil Research and Rehabilitation 7 (2), 145-146.

Ramankutty, N., Foley, J.A and Olejniczak, N.J. (2002b). People on the Land: Changes in Population and Global Croplands during the $20^{\text {th }}$ Century, Ambio, 31 (3), 251-257. 